\title{
地下水面の潮汐応答に関する解析解の導出と 伊豆諸島新島における原位置水理特性評価
}

\author{
愛知正温 ${ }^{*} \cdot$ 塩苅 恵 $^{* *} \cdot$ 德永朋祥 $* *$
}

\section{A new analytical solution of water table response to tidal fluctuations and its application to estimate aquifer properties at the Niijima Island, Japan}

\author{
Masaatsu AICHI*, Megumi SHIOKARI** and Tomochika TOKUNAGA***
}

\begin{abstract}
A perturbation solution of the Boussinesq equation under the boundary condition of multi-tide at the coast was derived for evaluating the hydraulic parameters of phreatic aquifer from tidally induced fluctuation of water table. Then, the solution was applied to estimate the hydraulic parameters of the Shiro-mama formation at the Niijima Island, Japan, by fitting the solution to the results of continuous measurements of water table fluctuations. The estimated hydraulic transmissivities from both the amplitude and the phase were comparable and consistent with the results of analyses based on DupuitGhyben-Herzberg model, suggesting that the obtained values, i.e., $0.12-1.7 \mathrm{~m}^{2} / \mathrm{s}$ were reasonable.
\end{abstract}

Key Words: tidal response, phreatic aquifer, transmissivity, Niijima Island

要 旨

地下水面の潮汐応答データを用いて原位置における沿岸不圧帯水層の物性評価を行うため、主要 四分潮から成る潮位変動の境界条件の下でBoussinesq 方程式の摂動解を導いた。得られた摂動解を 用いて、伊豆諸島新島の白ママ層中の不圧帯水層の地下水面変動の時系列観測デー夕に対するパラ メータフィッティングを行い、帯水層物性評価を試みた。その結果、透水量係数が $0.12 \sim 1.7 \mathrm{~m}^{2} / \mathrm{s}$ であると推定された。この結果は、地下水面変動の振幅・位相のどちらからも同様な值が求められ おり、さらにDupuit-Ghyben-Herzberg モデルを用いた解析の結果とも矛盾しておらず、適切に評価 されたと考えられる。

キーワード：潮汐、不圧帯水層、水理特性、新島、白ママ層

* 東京大学大学院工学系研究科都市工学専攻（率 113-8656 東京都文京区本郷 7-3-1)

Department of Urban Engineering, School of Engineering, University of Tokyo

** 東京大学大学院新領域創成科学研究科海洋技術環境学専攻

*** 東京大学大学院新領域創成科学研究科環境システム学専攻 


\section{1. はじめに}

原位置において帯水層の水理特性を把握するこ とは、実フィールドを対象として地下水の流動お よびそれに伴う物質移行の予測・評価を行うため に必要であり、持続的な地下水利用や地下水環境 の保全・修復などのさまざまな分野において重要 であると考えられる。原位置の帯水層の水理特性 を評価する手法の一つとして、大気圧変動や潮汐 などの自然の擾乱に対する地下水応答デー夕を 取得して解析する技術があげられる。たとえば、 Rojstaczer and Agnew（1989）は、地球潮汐に対 する地下水位応答から多孔質弾性定数を評価する 手法について述べている。Rojstaczer (1988)、細 谷・徳永 (2008) は、大気圧変動に伴う間隙水圧 変動を用いて、透水係数を評価する手法を開発し ている。Wang and Davis (1996)や浦越ほか (2005) は、波浪や潮汐に対する間隙水圧応答を用いた海 底下の水理特性評価手法の可能性についても示し ている。また、Shih and Lin (2004) は、海岸に おける潮位変動に対する陸域の地下水位の応答 を用いた解析事例を示している。これらの手法 は、受動的な観測のみによって物性を評価する手 法であり、揚水試験やトレーサー試験などの従来 の手法と比較して、周辺の地下水環境に与える影 響が少ないという利点がある。しかしながら、こ れらの解析手法は、被圧帯水層を対象として開発 されてきており、不圧帯水層を対象とした解析手 法については、未だ確立されていないのが現状で ある。近年、Jha et al. (2003)、Jha et al. (2008)、 Rotzoll et al. (2008)、Carol et al. (2009) などが いくつか単純な条件を仮定して不圧带水層を対象 とした解析手法を提案しているが、実際のフィー ルドに近いと考えられる複数分潮からなる潮位変 動を境界条件とする不圧帯水層を対象とし、観測 した地下水位変動を周波数方向に成分分離して応 答を解析する手法については、これまで検討され ていない。

我が国の離島の中には、沿岸の不圧帯水層から の地下水利用を行っているところもあり（磯崎、 1970 ; 新島村、1996)、不圧帯水層の水理特性を 評価することは重要であると考えられる。そこで、 本研究では、海洋潮汐に対する沿岸不圧带水層の
地下水面応答を用いて水理特性を評価するための 解析手法を開発し、さらに伊豆諸島新島を対象と して、実際のフィールドデータを用いた解析を実 施し、水理特性を評価した結果について報告する。

\section{2. 対象地域}

新島は、伊豆諸島の一部を構成する火山島の一 つで、東京都心から南方約 $150 \mathrm{~km}$ の太平洋上に 位置し（図 1a）、南北約 $11.5 \mathrm{~km}$, 東西約 $3.2 \mathrm{~km}$ と南北に細長い島である。磯部・伊藤（2003）に よると、島の中南部には、向山火山の噴火の際に 堆積した流紋岩質の粗粒な火砕サージ堆積物（白 ママ層）からなる台地が分布している（図 1b）。 新島では、この白ママ層が主要な帯水層であり、 白ママ層中の不圧地下水を揚水して、水道用水源 として利用している（新島村、1996）。現地踏査 を実施したところ、新島では、定常的に海まで流 下する河川はなく、側溝などの出口も満潮時の海 水面より高いところにあった。従って、地下水面 変動の中に見られる潮汐の影響は、表流水の感潮 によるものではなく、主に海岸における潮位変動 の影響が帯水層中へ伝播したものと考えられる。 白ママ層の下位は流紋岩質の凝灰岩で、水理地質 学的基盤と考えられている（本間ほか、1974; 新 藤、1980)。新藤（1980）の電気探査結果および 新島村建設課（2001）のボーリングデータに基づ いて作成した基盤深度面分布を図 $1 \mathrm{c} に$ 示す。基 盤上面の深度は、調査対象地域全体としては、沿 岸付近で深く、島の内陸へ向かって浅くなる傾向 にある。

\section{3. 地下水面変動の連続計測}

\section{1 計測手法}

地下水位の連続計測は、図 1c 中に 1 から 5 の 番号で示した 5 地点の井戸で行った。これらの井 戸は、深度 $10 \sim 15 \mathrm{~m}$ 程度で、白ママ層中の不圧 地下水をくみ上げるために、かつて各戸から小集 落の単位で錐井されたものであるが、現在は村営 の水道が普及したために使用されていない。井戸 枠には、流紋岩質の「抗火石」を用いており、そ れが多孔質であるため、そのままスクリーンも 
a)

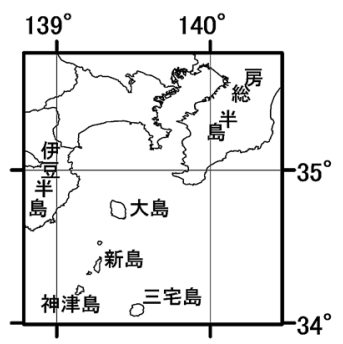

b) c)

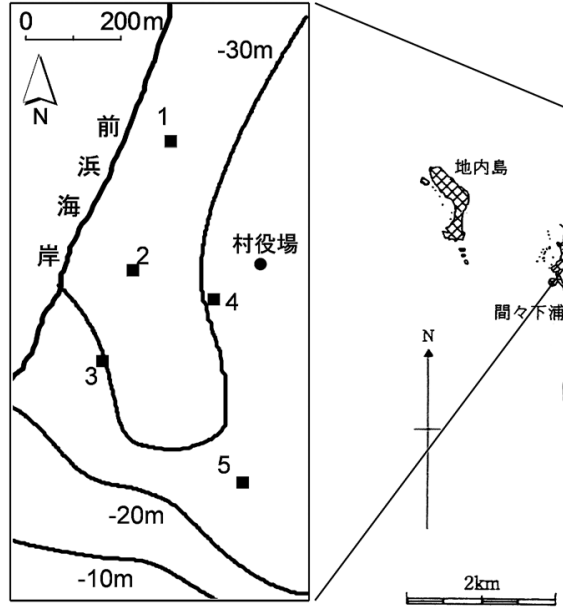

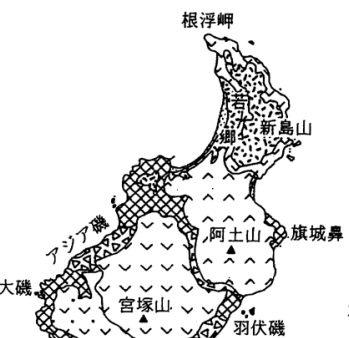

北側 砂浜堆樍物 砂丘堆積物

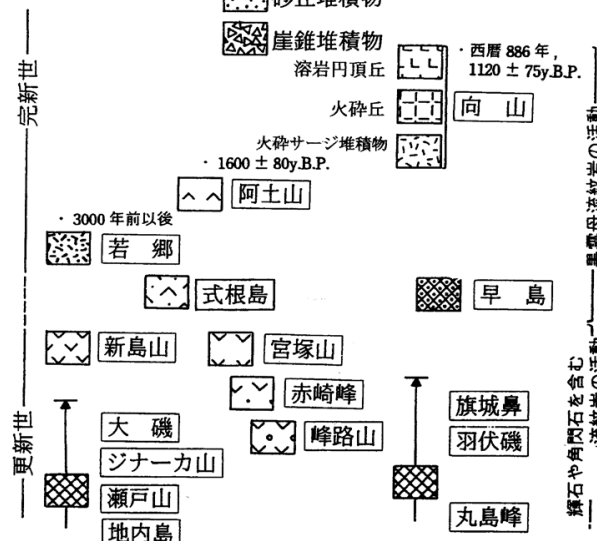

図 1 調查対象地域

a）新島の位置、b）新島の地質図（磯部·伊藤、2003）、c）観測井位置と基盤標高（基盤標高は、新藤（1980） および新島村建設課（2001）に基づいて作成）。

Fig. 1 Locality map of the study area. a) Location of the Niijima Island, b) Geological map of the Niijima Island (Isobe and Ito, 2003), c) Location of the observation wells and the elevation of the basement. Elevation of the basement was drawn from Shindo (1980) and Construction division of the Niijima Village (2001).

兼ねるようになっている。また、井戸径は数十 $\mathrm{cm} \sim 1 \mathrm{~m}$ 前後で、井戸口は大気開放されている。 水位の計測には, 水位計 (DIK-613A-A1 セラダ イバー $10 \mathrm{~m}$ 用、分解能 $2.5 \mathrm{mmH}_{2} \mathrm{O}$ ) 及び大気圧 計 (DIK-611A-E1 BARO ダイバー、分解能 2.5 $\mathrm{mmH}_{2} \mathrm{O}$ ）を使用した。各井戸の絶対標高を GPS 静止測量および水準測量により計測し、地下水面 の標高を求めた。

\section{2 計測結果}

2008 年 7 月 23 日 0:00 から 12 月 16 日 9:00 まで 10 分刻みで連続計測を行った結果を図 2 に 示す。ただし、井戸 2 は 10 月 16 日 $12: 00 、$ 井 戸 3 は 11 月 9 日 6:00で計測を終了した。また、 井戸 5 の 10 16日 11:00は欠測している。また、 比較のために近隣の神津島験潮所において同時期 に観測された潮位変動、大気圧および降水量（気
象庁、2008)についても図 2 に示した。図 2 からは、 地下水位の変動には、海洋潮汐に対する応答以外 に、9月20日に伊豆諸島を通過した台風 13 号の 影響と見られる水位上昇などの変動成分が含まれ ていることが分かる。

\section{3 地下水位変動の周期特性}

図 2 に示した地下水位変動の中には、降雨応答 や気圧応答、長期的な季節変動、水道用水源井の 揚水の影響、観測システムの誤差やドリフトなど、 さまざまな影響が含まれていると考えられる。し かし、これらの変動はそれぞれ周期が異なると考 えられるので、周波数方向に成分分離することに より区別できる可能性がある。そこで、地下水位 変動の周期特性を調べるために、全観測期間に対 して離散フーリエ変換を行った。なお、離散フー リエ変換に際しては、直流成分を除去した後に変 

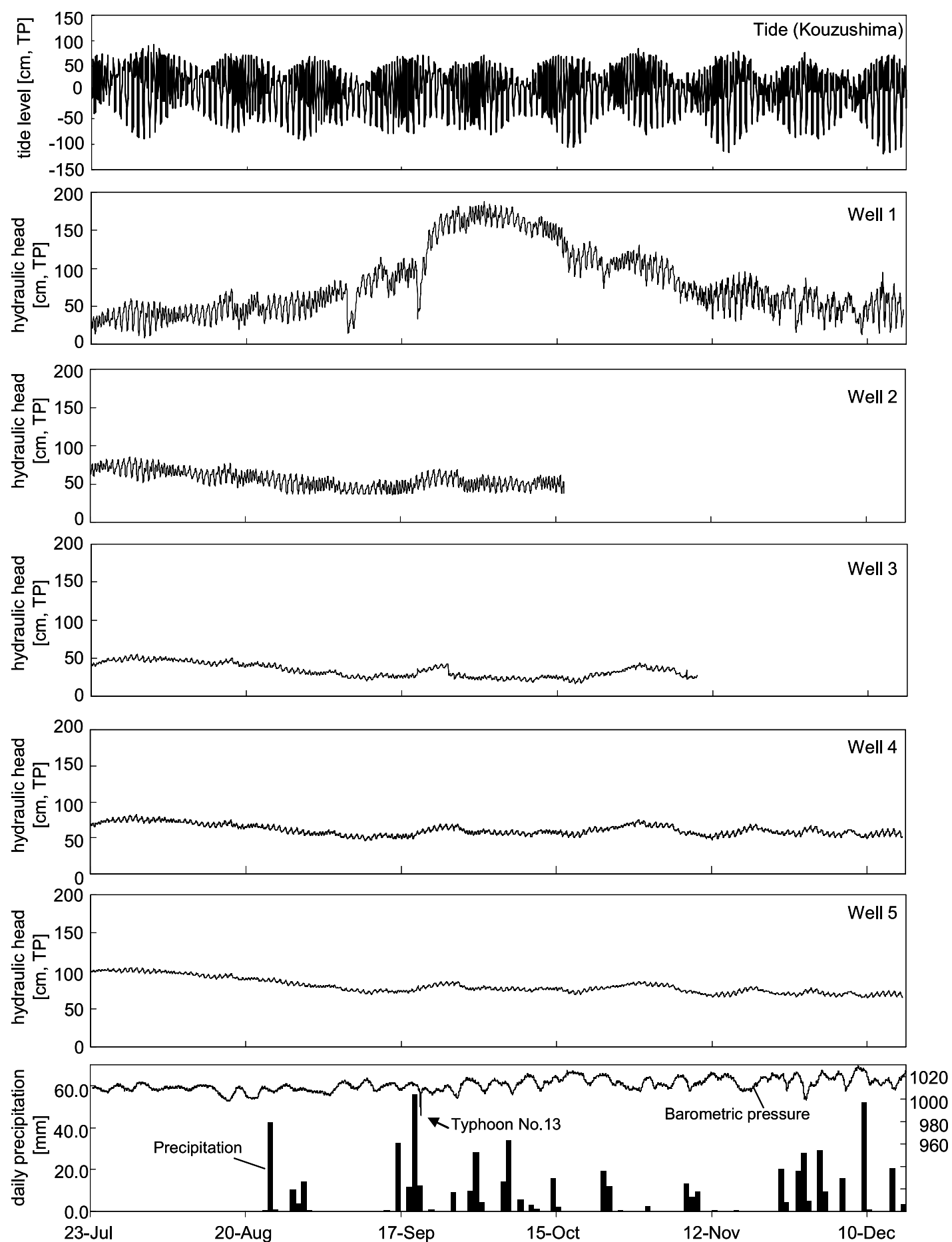

図 2 神津島の潮位変動（第三管区海上保安本部海洋情報部、2008）、井戸1～ 5 の水位変動、大気圧、日降水量 （気象庁、2008）の観測データ TPは、東京湾平均潮位を基準とした標高を意味する。

Fig. 2 Results of the observed data of ocean tide at the Kouzushima (Japan coast guard, 2008), water levels in the wells 1 to 5 , barometric pressure, and daily precipitation (Japan meteorological agency, 2008). TP represents the elevation from the Tokyo Peil. 
換を行った。各周期に対するパワースペクトルを 振幅に換算してまとめた結果を図 3 に示す。な お、比較のために近隣の神津島験潮所において同 時期に観測された潮位変動、大気圧および降水量 の離散フーリエ変換結果についても並べて示し た。図 3 からは、海洋潮汐がほとんど主要四分 潮、O1（主太陰日周潮、角周波数 $6.75977442 \times$ $10^{-5} \mathrm{rad} / \mathrm{s}$ )、 $\mathrm{K} 1$ (日月合成日周潮、角周波数 $7.29211584 \times 10^{-5} \mathrm{rad} / \mathrm{s}$ )、M2（主太陰半日周潮、 角周波数 $1.40518903 \times 10^{-4} \mathrm{rad} / \mathrm{s}$ )、S2（主太陽 半日周潮、角周波数 $1.45444104 \times 10^{-4} \mathrm{rad} / \mathrm{s}$ ） か らなっていることと、地下水位変動がその四分潮 と同周期の変動を含んでいることが認められる。 一方で、気圧、降水量については周期変動が明瞭 とはいえない。従って、本調査において、地下水 位変動を用いて水理特性評価を行う場合には、潮 汐に対する応答成分を利用することが最も有効で あると考えられる。

\section{4. 解析手法}

\section{1 海洋潮汐および地下水面変動データの調 和解析}

海洋の潮位変動および地下水面変動の潮汐調和 定数を求めるため、Baytap-G（石黒ほか、1984; Tamura et al., 1991) によって調和解析を行い、 主要四分潮の調和定数を求めた(表 1$)$ 。ここでは、 新島近傍の験潮所のなかで、神津島験潮所のほか に、阿古 (三宅島)、岡田 (大島) の各験潮所の 潮位デー夕（第三管区海上保安本部海洋情報部、 2008）を対象とした。本調查の期間では時間方向 のデー夕量が限られているため、 K1 潮、P1 潮（主 太陽日周潮)、S1 潮（気象日周潮）の間、および $\mathrm{S} 2$ 潮、 $\mathrm{K} 2$ 潮（日月合成半日周潮）の間の成分分 離は行わなかった。表 1 を見ると、潮位変動の振 幅については、各験潮所とも大きな差はないこと が分かる。一方で、位相については阿古と岡田が 似通っているのに対し、神津島だけがやや異なっ ていることが分かる。また、各観測井における地 下水面変動の振幅は、海岸からの距離が離れるほ ど、潮位変動の振幅に比べて減衰しているという 傾向が見られる。観測井における地下水面変動の 位相については、海岸からの距離によって变化し
ていることは分かるが、位相には $2 \pi$ ラジアンの 周期性があり、海岸からの距離と位相のずれの関 係については、表 1 からだけでは判然としない。

\section{2 主要四分潮を境界条件とする不圧帯水層 の潮汐応答の摄動解}

ここでは、新島が南北に長く東西方向に狭い島 であることから、近似的に無限の長さを持つ島 （infinite strip-island）の鉛直断面モデルを考える （図 4)。また、新島の海岸付近の塩淡境界の位置 や、その海洋潮汐に対する応答についてはこれま で調査されたことがなく、現時点ではその詳細 は不明である。本研究では、簡単のためSong $e t$ al. (2007) などの従来の解析的アプローチと同 様に塩淡境界の影響を考慮せず、淡水で満たされ た帯水層が海岸に露出しており、海岸において海 水面の変動と地下水面の変動が一致するとしてモ デル化することとした（図 4)。さらに、均質等 方な地盤を仮定し、地下水流れについて DupuitForchheimer 近似を仮定すると、支配方程式は Boussinesq 方程式となり、

$$
k \frac{\partial}{\partial x}\left(h \frac{\partial h}{\partial x}\right)=n_{e} \frac{\partial h}{\partial t}
$$

と表せる（Bear, 1972）。ここに、 $h$ は帯水層基盤 面から地下水面までの距離、 $x$ は海岸線からの距 離、 $t$ は時間、 $k$ は透水係数、 $n_{e}$ は有効間隙率である。

海岸における境界条件は、先述の通り、海水面 の変動と地下水面の変動が一致するとした。また、 島の両側の海岸で同様の潮位変動があると考える と、島の中央において対称である必要がある（図 4)。そこで、以下のような境界条件のもとで式 (1) を解くこととした。

$$
\begin{cases}h=D+\sum_{i=1}^{4} A_{i} \cos \left(\omega_{i} t+\theta_{i}\right) & \text { at } x=0 \\ \frac{\partial h}{\partial x}=0 & \text { at } x=M\end{cases}
$$

ここに、 $D$ は平均海面に対する基盤の深度、 $M$ は海岸から島の中央までの距離、 $A_{i} 、 \omega_{i} 、 \theta_{i}$ は、 それぞれ $i$ 番目の分潮の振幅、角周波数、位相遅 れを表し、ここでは 1 番がS2、2 番が M 2、3 番 
地下水学会誌 第 53 巻第 3 号 249 ～265（2011）
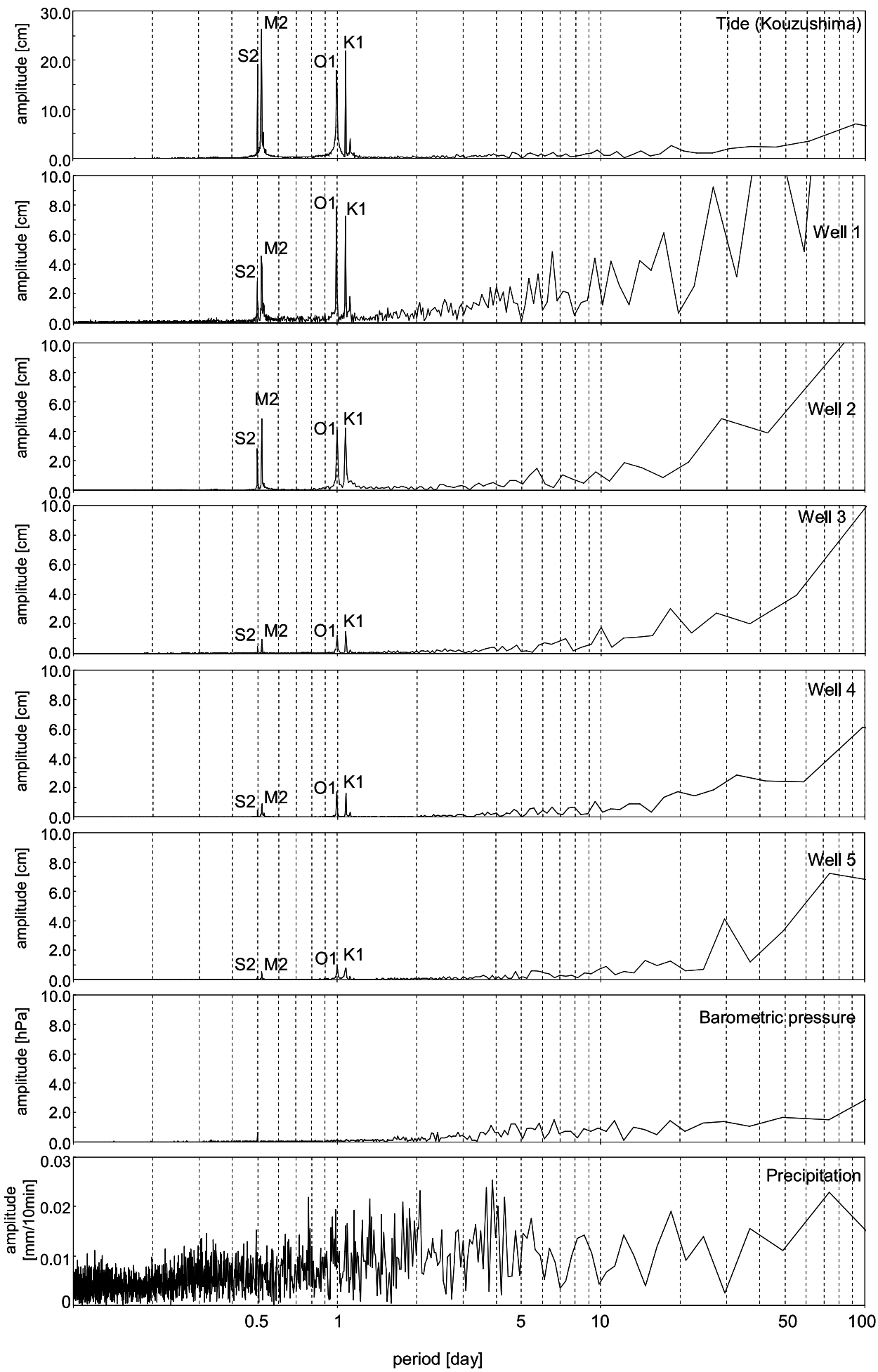

目 3 観測データの周期特性

詳細は本文を参照のこと。

Fig. 3 Period characteristics of the observed data. See text for details. 
表 1 新島近傍の験潮所の実測潮位および観測地下水位の潮汐調和定数

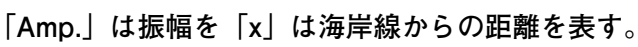

Table 1 Harmonic constants of tidal signals calculated from measured data at the tide stations near the Nijima Island and the observed water table fluctuations. "Amp." indicates amplitudes, and $\mathrm{x}$ indicates distance from the coast.

\begin{tabular}{|c|c|c|c|c|c|c|c|c|c|}
\hline & \multicolumn{3}{|c|}{$\mathrm{S} 2(\mathrm{~K} 2)$} & \multicolumn{2}{|c|}{ M2 } & \multicolumn{2}{|c|}{$\mathrm{K} 1(\mathrm{P} 1, \mathrm{~S} 1)$} & \multicolumn{2}{|c|}{$\mathrm{O} 1$} \\
\hline & $\begin{array}{c}\mathrm{x} \\
(\mathrm{m})\end{array}$ & $\begin{array}{c}\text { Amp. } \\
(\mathrm{cm})\end{array}$ & $\begin{array}{c}\text { Phase } \\
(\text { rad })\end{array}$ & $\begin{array}{c}\text { Amp. } \\
(\mathrm{cm})\end{array}$ & $\begin{array}{c}\text { Phase } \\
\text { (rad) }\end{array}$ & $\begin{array}{c}\text { Amp. } \\
(\mathrm{cm})\end{array}$ & $\begin{array}{c}\text { Phase } \\
(\text { rad })\end{array}$ & $\begin{array}{c}\text { Amp. } \\
(\mathrm{cm})\end{array}$ & $\begin{array}{c}\text { Phase } \\
(\text { rad })\end{array}$ \\
\hline $\begin{array}{c}\text { Kouzu- } \\
\text { shima } \\
\text { Ako }\end{array}$ & 0 & 17.9 & 2.97 & 39.6 & -2.84 & 23.7 & 3.00 & 18.7 & -2.91 \\
\hline $\begin{array}{l}\text { (Miyake } \\
\text {-jima) }\end{array}$ & 0 & 17.0 & 3.12 & 36.0 & 2.66 & 22.8 & 3.06 & 17.8 & 2.76 \\
\hline $\begin{array}{c}\text { Okada } \\
(\text { Oshima })\end{array}$ & 0 & 16.2 & 3.03 & 33.8 & 2.53 & 22.7 & 3.12 & 17.8 & 2.79 \\
\hline Well 1 & 110 & 3.1 & 0.56 & 6.5 & 1.14 & 7.2 & 1.58 & 6.7 & 1.95 \\
\hline Well 2 & 140 & 2.2 & 1.13 & 4.7 & 1.80 & 4.6 & 1.76 & 3.9 & 2.11 \\
\hline Well 3 & 160 & 0.5 & 0.16 & 0.9 & 0.81 & 1.5 & 0.88 & 1.2 & 1.24 \\
\hline Well 4 & 330 & 0.7 & 0.34 & 1.2 & 1.03 & 1.7 & 1.05 & 1.5 & 1.43 \\
\hline Well 5 & 540 & 0.4 & -0.32 & 0.6 & 0.21 & 1.2 & 0.56 & 1.0 & 0.96 \\
\hline
\end{tabular}

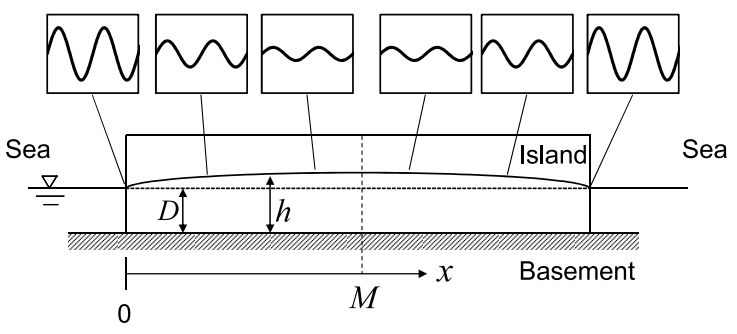

図 4 無限に細長い島の断面モデル

Fig. 4 Schematic cross section of a strip island model

が Kl、4 番が $\mathrm{O} 1$ を示すものとする。

Parlange et al. (1984）と同様の手法を用い、二 次の摂動解を、

$$
\begin{aligned}
& h=D\left[1+\sum_{i=1}^{4} \alpha_{i} h_{i}+\sum_{j=1}^{4} \sum_{k=j}^{4} \alpha_{k} \alpha_{j} h_{k j}+O\left(\alpha^{3}\right)\right] \\
& \text { とおく。ここで、 } \\
& \alpha_{i}=\frac{A_{i}}{D}(i=1,2,3,4)
\end{aligned}
$$$$
\text { （3）を得る。ただし }
$$

$$
\alpha=\operatorname{Max}\left(\alpha_{i}\right)
$$

である。ここで、図 $1 \mathrm{c} よ り$ 帯水層厚さ $D$ が $20 \mathrm{~m} \sim 40 \mathrm{~m}$ であることと、表 1 の海洋潮汐の振 幅データより $\frac{\alpha^{3}}{\alpha}<4 \times 10^{-4}$ であるから、 $O\left(\alpha^{3}\right)$ は、 $\mathrm{O}(\alpha)$ に比べて十分小さいとして差し支えないと 考えられる。

以下、Song et al. (2007) の手法と同様に、式 (3) を式（1）に代入し、 $\alpha_{i}$ のオーダーによって整理 し、連立微分方程式をたてる。まず、 $\alpha_{i}$ の項を 整理すると、

$$
c \frac{\partial^{2} h_{i}}{\partial x^{2}}=\frac{\partial h_{i}}{\partial t}
$$

$$
c=\frac{D k}{n_{e}}
$$


地下水学会誌 第 53 巻第 3 号 249 ～265（2011）

とおいた。また、式（2）は、

$$
\begin{cases}h=D\left[1+\sum_{i=1}^{4} \alpha_{i} \cos \left(\omega_{i} t+\theta_{i}\right)\right] & \text { at } x=0 \\ \frac{\partial h}{\partial x}=0 & \text { at } x=M\end{cases}
$$

と表せるので、境界条件に関しても、 $\alpha_{i}$ の項を 整理すると、

$$
\begin{cases}h_{i}=\cos \left(\omega_{i} t+\theta_{i}\right) & \text { at } x=0 \\ \frac{\partial h_{i}}{\partial x}=0 & \text { at } x=M\end{cases}
$$

となる。式 (6) を式 (9) の境界条件の下で解くと、

$$
\begin{aligned}
h_{i} & =P_{i}\left[e^{\lambda_{i}(x-2 M)} \cos \left(\omega_{i} t+\lambda_{i} x+\theta_{i}\right)\right. \\
& +e^{-\lambda_{i}(x-2 M)} \cos \left(\omega_{i} t-\lambda_{i} x+\theta_{i}\right) \\
& \left.+e^{\lambda_{i} x} \cos \left(\omega_{i} t+\lambda_{i} x-2 \lambda_{i} M+\theta_{i}\right)\right] \\
& \left.+e^{-\lambda_{i} x} \cos \left(\omega_{i} t-\lambda_{i} x+2 \lambda_{i} M+\theta_{i}\right)\right]
\end{aligned}
$$

を得る。ただし、

$$
\begin{aligned}
& \lambda_{i}=\sqrt{\frac{\omega_{i}}{2 c}} \\
& P_{i}=\frac{1}{2\left[\cosh \left(2 \lambda_{i} M\right)+\cos \left(2 \lambda_{i} M\right)\right]}
\end{aligned}
$$

である。なお、式（6）は Boussinesq 方程式の線 形近似であり、その解（10）は、水理拡散率 $c$ の 被圧帯水層中に打ける地下水応答の解析解と一致 する。

また、 $\alpha_{j} \alpha_{k}(j=k=m)$ の項について整理すると、

$$
\begin{aligned}
& c\left[\frac{\partial^{2} h_{m m}}{\partial x^{2}}+\frac{\partial}{d x}\left(h_{m} \frac{\partial h_{m}}{\partial x}\right)\right]=\frac{\partial h_{m m}}{\partial t} \\
& \begin{cases}h_{m m}=0 & \text { at } x=0 \\
\frac{\partial h_{m m}}{\partial x}=0 & \text { at } x=M\end{cases}
\end{aligned}
$$

となる。式（13）を式（14）の境界条件で解くと、

$$
\begin{aligned}
& h_{m m}=C_{1, m} e^{\sqrt{2} \lambda_{m} x} \cos \left(2 \omega_{m} t+\sqrt{2} \lambda_{m} x+2 \theta_{m}\right) \\
& +C_{2, m} e^{-\sqrt{2} \lambda_{m} x} \cos \left(2 \omega_{m} t-\sqrt{2} \lambda_{m} x+2 \theta_{m}\right) \\
& +C_{3, m} e^{\sqrt{2} \lambda_{m} x} \sin \left(2 \omega_{m} t+\sqrt{2} \lambda_{m} x+2 \theta_{m}\right) \\
& +C_{4, m} e^{-\sqrt{2} \lambda_{m} x} \sin \left(2 \omega_{m} t-\sqrt{2} \lambda_{m} x+2 \theta_{m}\right)+\tilde{h}_{m}
\end{aligned}
$$

である。ただし、

$$
\begin{aligned}
& \tilde{h}_{m}=-g_{m}(x, t)-\left(f_{m}(x)-f_{m}(0)\right) \\
& f_{m}(x)=\frac{P_{m}^{2}}{2}\left[\cosh \left(2 \lambda_{m}(x-2 M)\right)+\cos \left(2 \lambda_{m}(x-2 M)\right)\right. \\
& +\cosh 2 \lambda_{m} x+\cos 2 \lambda_{m} x+2 \cos 2 \lambda_{m} M \cosh \left(2 \lambda_{m}(x-M)\right) \\
& \left.+2 \cosh 2 \lambda_{m} M \cos \left(2 \lambda_{m}(x-M)\right)\right]
\end{aligned}
$$$$
\begin{aligned}
g_{m}(x, t) & =P_{m}{ }^{2}\left[\frac { 1 } { 2 } \left\{e^{2 \lambda_{m}(x-2 M)} \cos \left(2\left(\omega_{m} t+\theta_{m}\right)+2 \lambda_{m} x\right)\right.\right. \\
& +e^{-2 \lambda_{m}(x-2 M)} \cos \left(2\left(\omega_{m} t+\theta_{m}\right)-2 \lambda_{m} x\right) \\
& \left.+e^{2 \lambda_{m} x} \cos \left(2\left(\omega_{m} t+\theta_{m}\right)+2 \lambda_{m}(x-2 M)\right)\right\} \\
& +e^{-2 \lambda_{m} x} \cos \left(2\left(\omega_{m} t+\theta_{m}\right)-2 \lambda_{m}(x-2 M)\right) \\
& \left.+e^{2 \lambda_{m}(x-M)} \cos \left(2\left(\omega_{m} t+\theta_{m}\right)+2 \lambda_{m}(x-M)\right)\right] \\
& +e^{-2 \lambda_{m}(x-M)} \cos \left(2\left(\omega_{m} t+\theta_{m}\right)-2 \lambda_{m}(x-M)\right)
\end{aligned}
$$$$
C_{1, m}=Q_{m m}^{+}\left[\left\{1+e^{2 \sqrt{2} \lambda_{m} M} \cos \left(2 \sqrt{2} \lambda_{m} M\right)\right\} R_{m}\right.
$$$$
\left.+2 e^{2 \sqrt{2} \lambda_{m} M} \sinh \left(2 \lambda_{m} M\right) \sin \left(2 \sqrt{2} \lambda_{m} M\right) \sin \left(2 \lambda_{m} M\right)\right]
$$$$
C_{2, m}=Q_{m m}^{+} R_{m} e^{2 \sqrt{2} \lambda_{m} M}\left[e^{2 \sqrt{2} \lambda_{m} M}+\cos \left(2 \sqrt{2} \lambda_{m} M\right)\right]
$$

$C_{3, m}=Q_{m m}^{+}\left[e^{2 \sqrt{2} \lambda_{m} M} \sin \left(2 \sqrt{2} \lambda_{m} M\right) R_{m}\right.$$$
\left.-2\left\{1+e^{2 \sqrt{2} \lambda_{m} M} \cos \left(2 \sqrt{2} \lambda_{m} M\right)\right\} \sin \left(2 \lambda_{m} M\right) \sinh \left(2 \lambda_{m} M\right)\right]
$$

$C_{4, m}=-Q_{m m}^{+} e^{2 \sqrt{2} \lambda_{m} M}\left[R_{m} \sin \left(2 \sqrt{2} \lambda_{m} M\right)\right.$

$\left.+2\left\{\cos \left(2 \sqrt{2} \lambda_{m} M\right)+e^{2 \sqrt{2} \lambda_{m} M}\right\} \sin \left(2 \lambda_{m} M\right) \sinh \left(2 \lambda_{m} M\right)\right]$

$Q_{j k}^{+}=\frac{P_{j} P_{k}}{1+e^{4 \lambda_{j k}^{+} M}+2 e^{2 \lambda_{j k}^{+} M} \cos \left(2 \lambda_{j k}^{+} M\right)}$

$\lambda_{j k}^{+}=\sqrt{\frac{\omega_{j}+\omega_{k}}{2 c}}$ 


$$
\begin{aligned}
R_{m}= & \cos \left(4 \lambda_{m} M\right)+2 \cos \left(2 \lambda_{m} M\right) \cosh \left(2 \lambda_{m} M\right) \\
& +\cosh \left(4 \lambda_{m} M\right)
\end{aligned}
$$

である。次に、 $\alpha_{j} \alpha_{k}(j<k)$ の項を整理すると、

$$
\begin{aligned}
& c\left[\frac{\partial^{2} h_{j k}}{\partial x^{2}}+\frac{\partial^{2}\left(h_{j} h_{k}\right)}{\partial x^{2}}\right]=\frac{\partial h_{j k}}{\partial t} \\
& \left\{\begin{array}{l}
h_{j k}=0 \quad \text { at } x=0 \\
\frac{\partial h_{j k}}{\partial x}=0 \text { at } x=M
\end{array}\right.
\end{aligned}
$$

となる。式（26）を式（27）の境界条件の下で解 くと、 $j<k$ として、

$$
\begin{aligned}
& h_{j k}=C_{5, j k} e^{\lambda_{j k}^{+} x} \cos \left[\left(\omega_{j}+\omega_{k}\right) t+\lambda_{j k}^{+} x+\left(\theta_{j}+\theta_{k}\right)\right] \\
& +C_{6, j k} e^{-\lambda_{j k}^{+} x} \cos \left[\left(\omega_{j}+\omega_{k}\right) t-\lambda_{j k}^{+} x+\left(\theta_{j}+\theta_{k}\right)\right] \\
& +C_{7, j k} e^{\lambda_{j k}^{+} x} \sin \left[\left(\omega_{j}+\omega_{k}\right) t+\lambda_{j k}^{+} x+\left(\theta_{j}+\theta_{k}\right)\right] \\
& +C_{8, j k} e^{-\lambda_{j k}^{+} x} \sin \left[\left(\omega_{j}+\omega_{k}\right) t-\lambda_{j k}^{+} x+\left(\theta_{j}+\theta_{k}\right)\right] \\
& +C_{9, j k} e^{\lambda_{j k}^{-} x} \cos \left[\left(\omega_{j}-\omega_{k}\right) t+\lambda_{j k}^{-} x+\left(\theta_{j}-\theta_{k}\right)\right] \\
& +C_{10, j k} e^{-\lambda_{j k}^{-} x} \cos \left[\left(\omega_{j}-\omega_{k}\right) t-\lambda_{j k}^{-} x+\left(\theta_{j}-\theta_{k}\right)\right] \\
& +C_{11, j k} e^{\lambda_{j j k}^{-} x} \sin \left[\left(\omega_{j}-\omega_{k}\right) t+\lambda_{j k}^{-} x+\left(\theta_{j}-\theta_{k}\right)\right] \\
& +C_{12, j k} e^{-\lambda_{j k}^{-} x} \sin \left[\left(\omega_{j}-\omega_{k}\right) t-\lambda_{j k}^{-} x+\left(\theta_{j}-\theta_{k}\right)\right]+\hat{h}_{j k}
\end{aligned}
$$

が導かれる。ただし、

$$
\begin{aligned}
& \lambda_{j k}^{-}=\sqrt{\frac{\omega_{j}-\omega_{k}}{2 c}} \\
& C_{5, j k}=2 Q_{j k}^{+}\left[\left\{1+e^{2 \lambda_{j k}^{+} M} \cos \left(2 \lambda_{j k}^{+} M\right)\right\}\right. \\
& \left\{S_{j k}-B_{1, j k} \sin \left(2 \lambda_{j} M\right) \sin \left(2 \lambda_{k} M\right)\right\} \\
& \left.-\left(1-B_{1, j k}\right) e^{2 \lambda_{j k}^{+} M} \sin \left(2 \lambda_{j k}^{+} M\right) U_{j k}\right] \\
& C_{6, j k}=2 Q_{j k}^{+} e^{2 \lambda_{j k}^{+} M}\left[\left\{e^{2 \lambda_{j k}^{+} M}+\cos \left(2 \lambda_{j k}^{+} M\right)\right\}\right. \\
& \left\{S_{j k}-B_{1, j k} \sin \left(2 \lambda_{j} M\right) \sin \left(2 \lambda_{k} M\right)\right\} \\
& \left.+\left(1-B_{1, j k}\right) \sin \left(2 \lambda_{j k}^{+} M\right) V_{j k}\right]
\end{aligned}
$$

$S_{j k}=\cosh \left[2\left(\lambda_{j}-\lambda_{k}\right) M\right]+\cos \left[2\left(\lambda_{j}-\lambda_{k}\right) M\right]$

$+\cos \left(2 \lambda_{j} M\right) \cosh \left(2 \lambda_{k} M\right)+\cosh \left(2 \lambda_{j} M\right)$ $\cos \left(2 \lambda_{k} M\right)+B_{1, j k} \sinh \left(2 \lambda_{j} M\right) \sinh \left(2 \lambda_{k} M\right)$ 


$$
\begin{aligned}
& T_{j k}=\left\{\cos \left(2 \lambda_{j} M\right)+\cosh \left(2 \lambda_{j} M\right)\right\}\left\{\cos \left(2 \lambda_{k} M\right)+\cosh \left(2 \lambda_{k} M\right)\right\} \\
& +B_{2, j k}\left\{\sinh \left(2 \lambda_{j} M\right) \sin \left(2 \lambda_{k} M\right)-\sin \left(2 \lambda_{j} M\right) \sinh \left(2 \lambda_{k} M\right)\right\} \\
& U_{j k}=\sin \left(2 \lambda_{j} M\right) \sin \left(2 \lambda_{k} M\right) \\
& +\sinh \left(2 \lambda_{j} M\right) \sinh \left(2 \lambda_{k} M\right) \\
& V_{j k}=\sinh \left(2 \lambda_{j} M\right) \sin \left(2 \lambda_{k} M\right) \\
& +\sin \left(2 \lambda_{j} M\right) \sinh \left(2 \lambda_{k} M\right) \\
& Q_{j k}^{-}=\frac{P_{j} P_{k}}{1+e^{4 \lambda_{j k}^{-} M}+2 e^{2 \lambda_{j k}^{j} M} \cos \left(2 \lambda_{j k}^{-} M\right)}
\end{aligned}
$$

である。また、

$$
\zeta_{0, j k}=\left(\omega_{j}-\omega_{k}\right) t+\left(\theta_{j}-\theta_{k}\right)-\left(\lambda_{j}-\lambda_{k}\right) x
$$

$$
\begin{aligned}
& \zeta_{1, j k}=\left(\omega_{j}-\omega_{k}\right) t+\left(\theta_{j}-\theta_{k}\right)-\left(\lambda_{j}+\lambda_{k}\right) x \\
& \zeta_{2, j k}=\left(\omega_{j}-\omega_{k}\right) t+\left(\theta_{j}-\theta_{k}\right)+\left(\lambda_{j}-\lambda_{k}\right) x \\
& \zeta_{3, j k}=\left(\omega_{j}-\omega_{k}\right) t+\left(\theta_{j}-\theta_{k}\right)+\left(\lambda_{j}+\lambda_{k}\right) x \\
& \zeta_{4, j k}=\left(\omega_{j}+\omega_{k}\right) t+\left(\theta_{j}+\theta_{k}\right)-\left(\lambda_{j}-\lambda_{k}\right) x \\
& \zeta_{5, j k}=\left(\omega_{j}+\omega_{k}\right) t+\left(\theta_{j}+\theta_{k}\right)-\left(\lambda_{j}+\lambda_{k}\right) x \\
& \zeta_{6, j k}=\left(\omega_{j}+\omega_{k}\right) t+\left(\theta_{j}+\theta_{k}\right)+\left(\lambda_{j}-\lambda_{k}\right) x \\
& \zeta_{7, j k}=\left(\omega_{j}+\omega_{k}\right) t+\left(\theta_{j}+\theta_{k}\right)+\left(\lambda_{j}+\lambda_{k}\right) x
\end{aligned}
$$

$$
\begin{aligned}
& \hat{h}_{j k}=-\frac{P_{j} P_{k}}{2}\left[e^{\left(\lambda_{j}+\lambda_{k}\right)(x-2 M)}\left\{B_{1, j k} \cos \left(\zeta_{7, j k}\right)+\cos \left(\zeta_{2, j k}\right)-B_{2, j k} \sin \left(\zeta_{2, j k}\right)\right\}\right. \\
& +e^{\left(\lambda_{j}-\lambda_{k}\right)(x-2 M)}\left\{\left(2-B_{1, j k}\right) \cos \left(\zeta_{6, j k}\right)+\cos \left(\zeta_{3, j k}\right)+B_{2, j k} \sin \left(\zeta_{3, j k}\right)\right\} \\
& +e^{-\left(\lambda_{j}+\lambda_{k}\right)(x-2 M)}\left\{B_{1, j k} \cos \left(\zeta_{5, j k}\right)+\cos \left(\zeta_{0, j k}\right)-B_{2, j k} \sin \left(\zeta_{0, j k}\right)\right\} \\
& +e^{-\left(\lambda_{j}-\lambda_{k}\right)(x-2 M)}\left\{\left(2-B_{1, j k}\right) \cos \left(\zeta_{4, j k}\right)+\cos \left(\zeta_{1, j k}\right)+B_{2, j k} \sin \left(\zeta_{1, j k}\right)\right\} \\
& +e^{\left(\lambda_{j}+\lambda_{k}\right) x-2 \lambda_{j} M}\left\{B_{1, j k} \cos \left(\zeta_{7, j k}-2 \lambda_{k} M\right)+\cos \left(\zeta_{2, j k}+2 \lambda_{k} M\right)-B_{2} \sin \left(\zeta_{2, j k}+2 \lambda_{k} M\right)\right\} \\
& +e^{\left(\lambda_{j}-\lambda_{k}\right) x-2 \lambda_{j} M}\left\{\left(2-B_{1, j k}\right) \cos \left(\zeta_{6, j k}+2 \lambda_{k} M\right)+\cos \left(\zeta_{3, j k}-2 \lambda_{k} M\right)+B_{2, j k} \sin \left(\zeta_{3, j k}-2 \lambda_{k} M\right)\right\} \\
& +e^{-\left(\lambda_{j}+\lambda_{k}\right) x+2 \lambda_{j} M}\left\{B_{1, j k} \cos \left(\zeta_{5, j k}+2 \lambda_{k} M\right)+\cos \left(\zeta_{0, j k}-2 \lambda_{k} M\right)-B_{2, j k} \sin \left(\zeta_{0, j k}-2 \lambda_{k} M\right)\right\} \\
& +e^{-\left(\lambda_{j}-\lambda_{k}\right) x+2 \lambda_{j} M}\left\{\left(2-B_{1, j k}\right) \cos \left(\zeta_{4, j k}-2 \lambda_{k} M\right)+\cos \left(\zeta_{1, j k}+2 \lambda_{k} M\right)+B_{2, j k} \sin \left(\zeta_{1, j k}+2 \lambda_{k} M\right)\right\} \\
& +e^{\left(\lambda_{j}+\lambda_{k}\right) x-2 \lambda_{k} M}\left\{B_{1, j k} \cos \left(\zeta_{7, j k}-2 \lambda_{j} M\right)+\cos \left(\zeta_{2, j k}-2 \lambda_{j} M\right)-B_{2, j k} \sin \left(\zeta_{2, j k}-2 \lambda_{j} M\right)\right\} \\
& +e^{\left(\lambda_{j}-\lambda_{k}\right) x+2 \lambda_{k} M}\left\{\left(2-B_{1, j k}\right) \cos \left(\zeta_{6, j k}-2 \lambda_{j} M\right)+\cos \left(\zeta_{3, j k}-2 \lambda_{j} M\right)+B_{2, j k} \sin \left(\zeta_{3, j k}-2 \lambda_{j} M\right)\right\} \\
& +e^{-\left(\lambda_{j}+\lambda_{k}\right) x+2 \lambda_{k} M}\left\{B_{1, j k} \cos \left(\zeta_{5, j k}+2 \lambda_{j} M\right)+\cos \left(\zeta_{0, j k}+2 \lambda_{j} M\right)-B_{2, j k} \sin \left(\zeta_{0, j k}+2 \lambda_{j} M\right)\right\} \\
& +e^{-\left(\lambda_{j}-\lambda_{k}\right) x-2 \lambda_{k} M}\left\{\left(2-B_{1, j k}\right) \cos \left(\zeta_{4, j k}+2 \lambda_{j} M\right)+\cos \left(\zeta_{1, j k}+2 \lambda_{j} M\right)+B_{2, j k} \sin \left(\zeta_{1, j k}+2 \lambda_{j} M\right)\right\} \\
& +e^{\left(\lambda_{j}+\lambda_{k}\right) x}\left\{B_{1, j k} \cos \left(\zeta_{7, j k}-2\left|\lambda_{j}+\lambda_{k}\right| M\right)+\cos \left(\zeta_{2, j k}-2\left|\lambda_{j}-\lambda_{k}\right| M\right)-B_{2, j k} \sin \left(\zeta_{2, j k}-2\left|\lambda_{j}-\lambda_{k}\right| M\right)\right\} \\
& +e^{\left(\lambda_{j}-\lambda_{k}\right) x}\left\{\left(2-B_{1, j k}\right) \cos \left(\zeta_{6, j k}-2\left|\lambda_{j}-\lambda_{k}\right| M\right)+\cos \left(\zeta_{3, j k}-2\left|\lambda_{j}-\lambda_{k}\right| M\right)+B_{2} \sin \left(\zeta_{3, j k}-2\left|\lambda_{j}-\lambda_{k}\right| M\right)\right\} \\
& +e^{-\left(\lambda_{j}+\lambda_{k}\right) x}\left\{B_{1, j k} \cos \left(\zeta_{5, j k}+2\left|\lambda_{j}+\lambda_{k}\right| M\right)+\cos \left(\zeta_{0, j k}+2\left|\lambda_{j}-\lambda_{k}\right| M\right)-B_{2, j k} \sin \left(\zeta_{0, j k}+2\left|\lambda_{j}-\lambda_{k}\right| M\right)\right\} \\
& \left.+e^{-\left(\lambda_{j}-\lambda_{k}\right) x}\left\{\left(2-B_{1, j k}\right) \cos \left(\zeta_{4, j k}+2\left|\lambda_{j}-\lambda_{k}\right| M\right)+\cos \left(\zeta_{1, j k}+2\left|\lambda_{j}+\lambda_{k}\right| M\right)+B_{2, j k} \sin \left(\zeta_{1, j k}+2\left|\lambda_{j}+\lambda_{k}\right| M\right)\right\}\right]
\end{aligned}
$$


と表せる。

ここで、 $\omega_{2}=\omega_{3}+\omega_{4}$ であるから、 $h_{34}$ には $h_{2}$ と 同周期の成分、 $h_{24}$ には $h_{3}$ と同周期の成分、 $h_{23}$ に は $h_{4}$ と同周期の成分が、それぞれ含まれている ことが分かる。

\section{3 パラメータフィッティングの手法}

前節までに導いた $h_{i}$ および $h_{j k}$ （式（10）、(15)、 (28)）は、式（6）、（13）、（26）の解であるから、 帯水層物性については、式（6）、（13）、（26）に 現れている $c$ にのみ依存する。よって、式 (3) に式（10）、（15）、（28）を代入して得られる最終 的な地下水面変動の解において、位相遅れは $c$ に のみ依存する。また、振幅については、式（3） の最初に係数 $D$ があるため、 $c$ および $D$ の両方 に依存する可能性がある。帯水層厚さ $D$ につい ては、平均潮位から基盤までの距離であるから、 図 1c からある程度推測可能であるが、基盤面が 完全に平坦ではないことや詳細な分布については 不確実性があることから、ここでは $20 ４ 0 \mathrm{~m}$ の 幅を持つフィッティングパラメータとして扱うこ ととした。

地下水面変動の振幅を用いて $D$ および $c$ につ いて、また位相差を用いて $c$ についてパラメータ フィッティングを行い、それぞれ平方平均二乗誤 差（Root Mean Square Error, 以下 RMSE) を最 小とするパラメータセットを探索した。なお、本 論文では、観測上の振幅の大きい分潮ほどパラ メータフィッティングの際の優先度が高くなるよ う、観測水位変動の振幅で重み付けした RMSE を定義した。すなわち、振幅に関する RMSE は、

$$
R M S E=\sqrt{\frac{1}{4 \sum_{n=1}^{4} a_{n, o b s}} \sum_{m=1}^{4} a_{m, o b s}\left(a_{m, c a l}-a_{m, o b s}\right)^{2}}
$$

と定め、位相差に関する RMSE は、

$$
R M S E=\sqrt{\frac{1}{4 \sum_{n=1}^{4} a_{n, o b s}} \sum_{m=1}^{4} a_{m, o b s} \min \left[\left(\theta_{m, c a l}-\theta_{m, o b s}\right)^{2},\left(\theta_{m, c a l} \pm 2 \pi-\theta_{m, o b s}\right)^{2}\right]}
$$

と定めた。ここに、 $\alpha_{m, c a l} 、 \alpha_{m, b s}$ は、それぞれ $m$ 番目の分潮と同周期の地下水面変動振幅の計算值 と観測值、 $\theta_{m, c a l} 、 \theta_{m, b s}$ は、それぞれ $m$ 番目の
分潮と同周期の地下水面変動の位相差（観測開始 時刻基準)の計算值と観測值である。解析解に代 入する沿岸の潮位変動の潮汐調和定数は、表 1 に 示した神津島、阿古 (三宅島)、岡田 (大島) の 3 つの験潮所の值をそれぞれ用いて、3 通りの計 算を行った。

\section{5. 水理特性の推定結果と考察}

まず、 $D$ および $c$ を決定する際の一意性につい て検討するため、 $D$ および $c$ の值を変化させた場 合に、RMSEがどのように変化するかについて調 べた。その結果を図 5 および図 6 に示す。図 5 から、 $D$ が振幅に対して持つ感度は低いことが分かる。 従って、基盤深度は他の調查手法によって独立に 決定されることが必要であると考えられる。一方 で、cについては、よく決定できることが示唆さ れている。水位計の分解能が $0.25 \mathrm{~cm}$ であること から、図 5 中 RMSE $<0.25 \mathrm{~cm}$ の領域については 推定誤差の範囲であるとすると、海岸に近い井戸 では RMSE $<0.25 \mathrm{~cm}$ の領域が狭く、 $c$ の推定精 度が良いと考えられる。図 6 では、RMSEが極小 值をとるような $c$ が複数存在することが分かる。 これは位相遅れが $2 \pi$ [ rad] の周期性を持つため であり、位相遅れデー夕のみからでは、 $c$ を唯一 に決定することが難しいことを示している。また、 図 6 からは、位相差に関して験潮所間で RMSE の最小值を比較すると、神津島験潮所の RMSE が最も小さいことも読み取れる。このことから、 三つの験潮所のデータのうち、神津島験潮所デー 夕で新島の前浜海岸における潮位変動を近似する のが、地下水観測データともっとも整合性がよい ことが分かる。

次に、RMSE 最小時の振幅及び位相差の計算值 と観測結果の比較を図 7 および図 8 に示した。神 津島験潮所の潮汐調和定数を用いると、RMSE が 最小となるパラメータセットにより計算された振 幅及び位相差はともに観測結果と調和的であり、 帯水層パラメー夕は適切に評価できているものと 考えられる。また、図 8 からも神津島験潮所の潮 汐調和定数を用いた計算結果が観測結果に対して 最も整合的であることが読み取れる。

神津島験潮所のデータを用いてパラメータ 


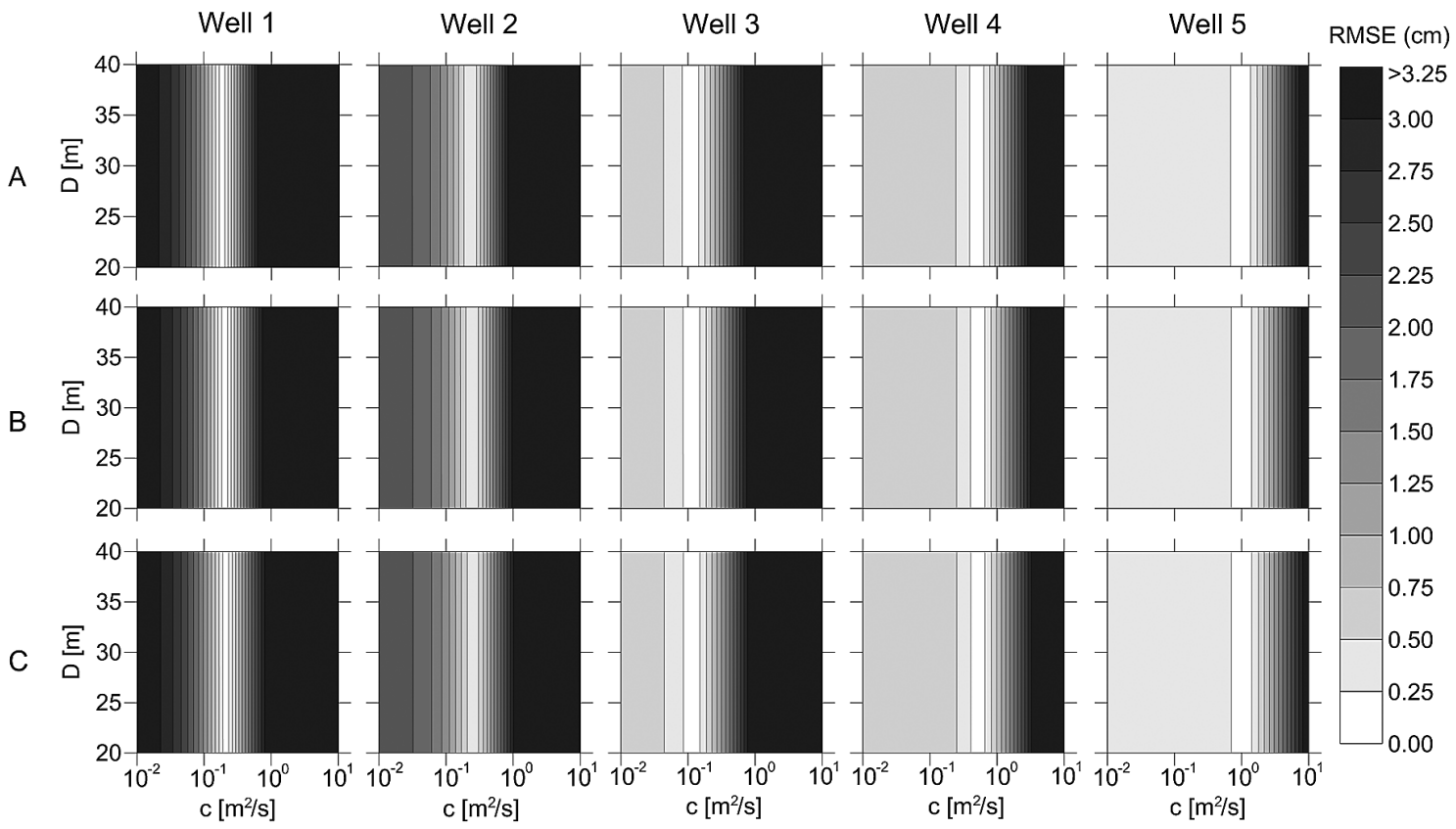

图 5 D と c をパラメータにとった場合の振幅に対する平方平均二乗誤差（RMSE）

A は神津島験潮所、B は阿古験潮所（三宅島）、C は岡田験潮所（大島）の潮汐調和定数（表 1）を用いて 計算した結果。

Fig. 5 Root mean square errors (RMSE) obtained from the parameter fitting for amplitudes. A, B and C are the results using the harmonic constants of tides at Kouzushima, Ako, and Okada (Table 1), respectively.
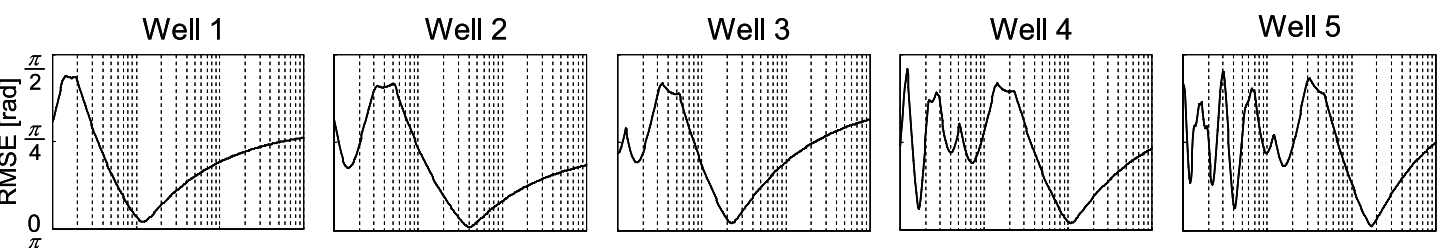

\section{$\mathrm{B}$}
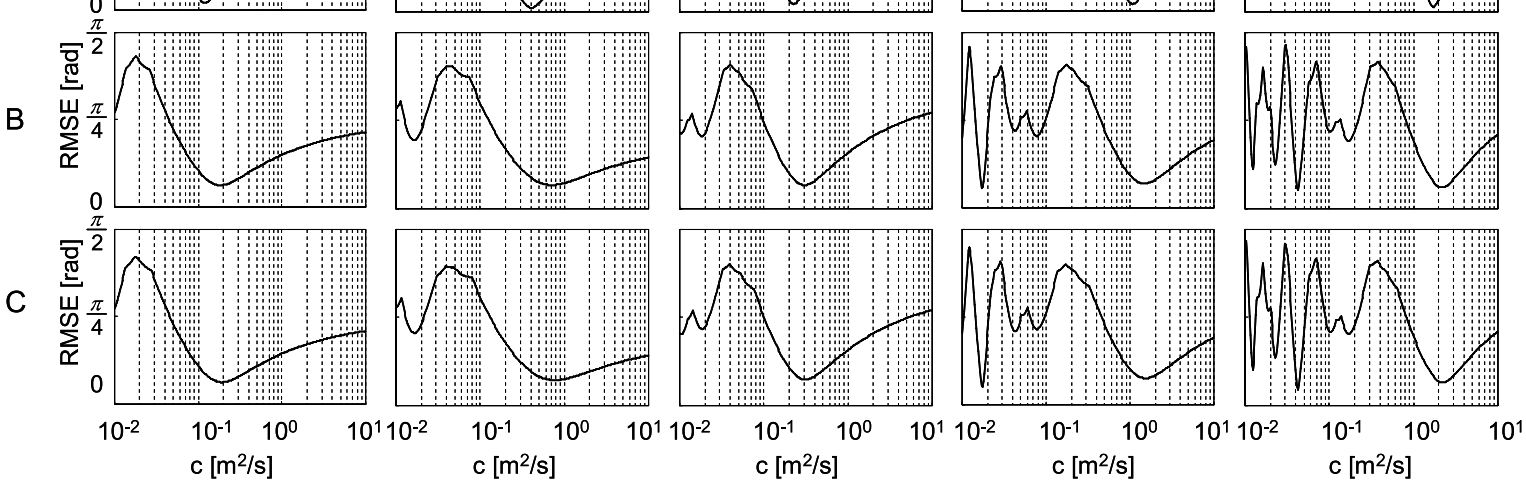

图 6 c をパラメータにとった場合の位相に対する平方平均二乗誤差（RMSE）

A は神津島験潮所、B は阿古験潮所（三宅島）、C は岡田験潮所（大島）の潮汐調和定数（表 1）を用いて 計算した結果。

Fig. 6 Root mean square errors (RMSE) obtained from the parameter fitting for phase. A, B and C are the results using the harmonic constants of tides at Kouzushima, Ako, and Okada (Table 1), respectively. 

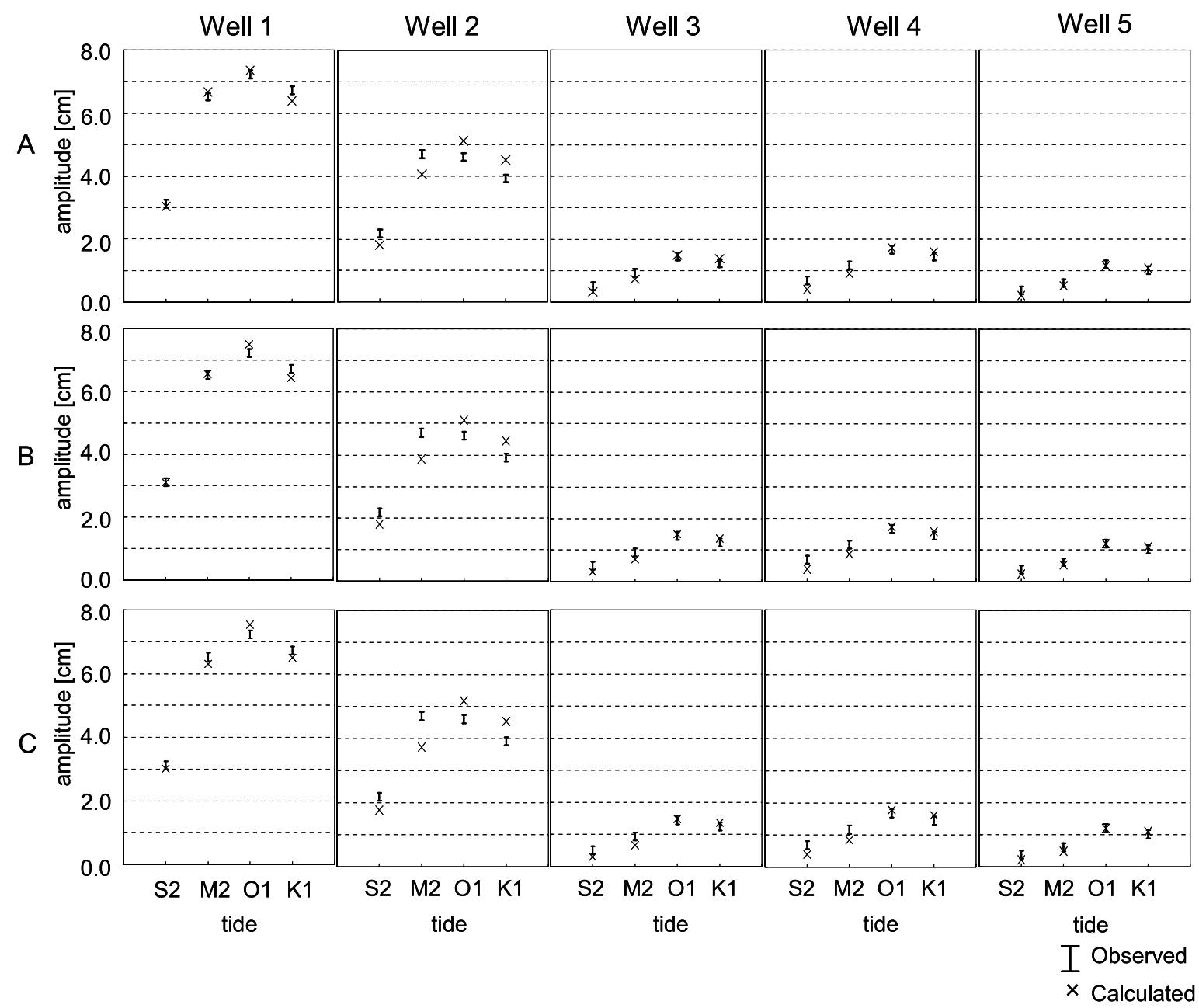

図 7 主要四分潮と同周期の地下水面変動成分の振幅に関して、平方平均二乗誤差 (RMSE) が最小となるような パラメータを用いた場合の計算値と観測値の比較。A は神津島験潮所、B は阿古験潮所（三宅島）、C は岡 田験潮所 (大島) の潮汐調和定数（表 1）を用いて計算した結果。観測値のエラーバーは計測分解能を表す。

Fig. 7 Comparisons between the calculated and observed amplitudes of water table fluctuations for the major tidal components. The parameters for the calculation were chosen as the RMSE to be minimum. A, B and $C$ are the results using the harmonic constants of tides at Kouzushima, Ako, and Okada (Table 1), respectively. The error bars of the observed values indicate the resolutions of the observation system.

フィッティングを行った結果に基づき、RMSE を最小とするような $c$ を求めた結果を表 2 に示し た。振幅を用いて得られた $c$ と、位相差を用いて 得られた $c$ の值は、2 倍以内で収まっており、整 合的な結果が得られている。また、得られた $c$ の 值について、井戸間での差異は 1 オーダー程度に 収まっており、白ママ層は比較的均質な透水量係 数を持つ带水層であることを示唆している。

さらに、得られた透水量係数と既存資料に基づ
いて透水係数の推定を試みた。白ママ層の有効間 隙率は、新藤ほか（1989）が採取試料の室内試験 により求めた白ママ層の毛管圧曲線から、10〜 40\%程度であることが分かっている。これと、帯 水層厚さ $20 \sim 40 \mathrm{~m}$ に基づいて透水係数を求める と、 $3.0 \times 10^{-4} \sim 3.4 \times 10^{-2} \mathrm{~m} / \mathrm{s}$ 程度と推定さ れる。

ここで、上記の透水係数推定結果の妥当性につ いて、strip-island を対象とした Dupuit-Ghyben- 


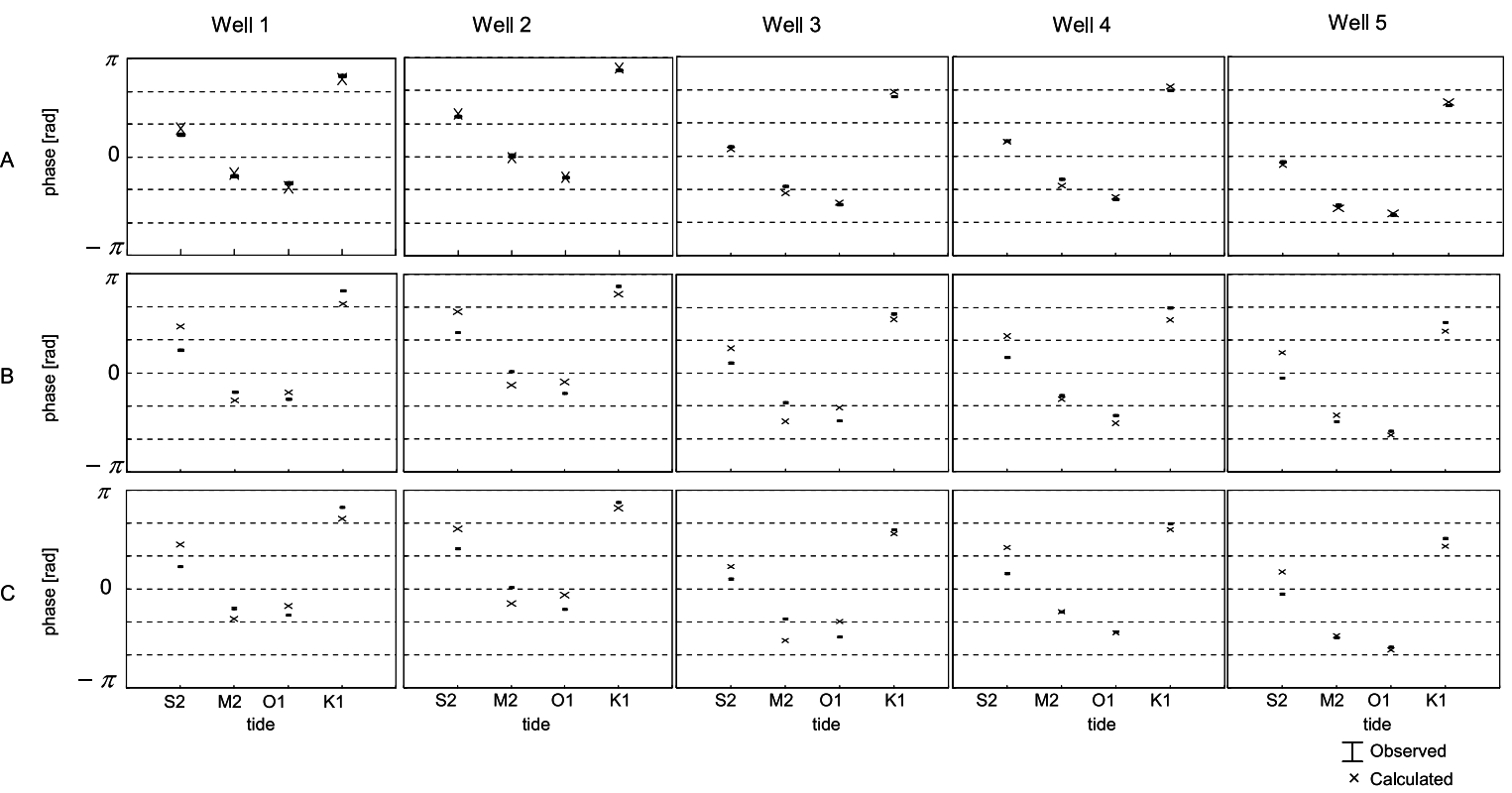

図 8 主要四分潮と同周期の地下水面変動成分の位相に関して、平方平均二乗誤差 (RMSE) が最小となるような パラメータを用いた場合の計算值と観測値の比較。A は神津島験潮所、B は阿古験潮所（三宅島）、C は岡 田験潮所 (大島) の潮汐調和定数（表 1）を用いて計算した結果。観測値のエラーバーは計測分解能を表す。

Fig. 8 Comparisons between the calculated and observed phase shifts of water table fluctuations for the major tidal components. The parameters for the calculation were chosen as the RMSE to be minimum. A, B and $C$ are the results using the harmonic constants of tides at Kouzushima, Ako, and Okada (Table 1), respectively. The error bars of the observed values indicate the resolutions of the observation system.

表 2 透水量係数の推定結果

$\mathrm{x}$ は海岸線からの距離を示す。

Table 2 Estimated hydraulic transmissibities. $x$ indicates distance from the coast.

\begin{tabular}{cccc}
\hline Well & $\mathrm{x}(\mathrm{m})$ & $\begin{array}{c}\mathrm{c}\left(\mathrm{m}^{2} / \mathrm{s}\right) \\
\text { Amplitude) }\end{array}$ & $\begin{array}{c}\mathrm{c}\left(\mathrm{m}^{2} / \mathrm{s}\right) \\
(\text { Phase } \\
\text { shift })\end{array}$ \\
\hline 1 & 110 & 0.18 & 0.12 \\
2 & 140 & 0.23 & 0.41 \\
3 & 160 & 0.12 & 0.22 \\
4 & 330 & 0.51 & 1.0 \\
5 & 540 & 1.0 & 1.7 \\
\hline
\end{tabular}

Herzberg モデル（Vacher, 1988）を用いて考察す る。Vacher（1988）によると、透水係数 $k$ 、全幅 $2 M$ の strip-island で、涵養量が $R$ の場合、海岸か らの距離 $x$ の地点の地下水面標高 $\mathrm{h}_{\mathrm{lenz}}$ は、

$$
h_{\text {lenz }}=\sqrt{\frac{R}{k} \frac{\rho_{s}-\rho_{f}}{\rho_{f}}\left(2 M x-x^{2}\right)}
$$

により表される。ただし、 $\rho_{s}$ は海水の密度、 $\rho_{f}$ は淡水の密度である。式（56）を用いて、 $\frac{R}{k}$ を変化させながら、観測水位と比較したものを図 9 に示す。なお、観測水位は、解析解を用いて潮 汐の影響による変動を取り除いたものから、7月 23 日の正午の值を用いている。観測開始直後の 值を使用しているのは、観測システムのドリフト などによる誤差を含む可能性がもっとも低いと考 えられるためである。図 9 からは、 $\frac{R}{k}$ が $2 \sim 4 \times$ $10^{-5}$ 程度であることが分かる。本間ほか(1974)は、 白ママ層を対象として浸透量を計測し、降雨量の 30 ～50\%程度が地下へ浸透しているという結果 を得ている。この結果に基づくと、新島の平年降 


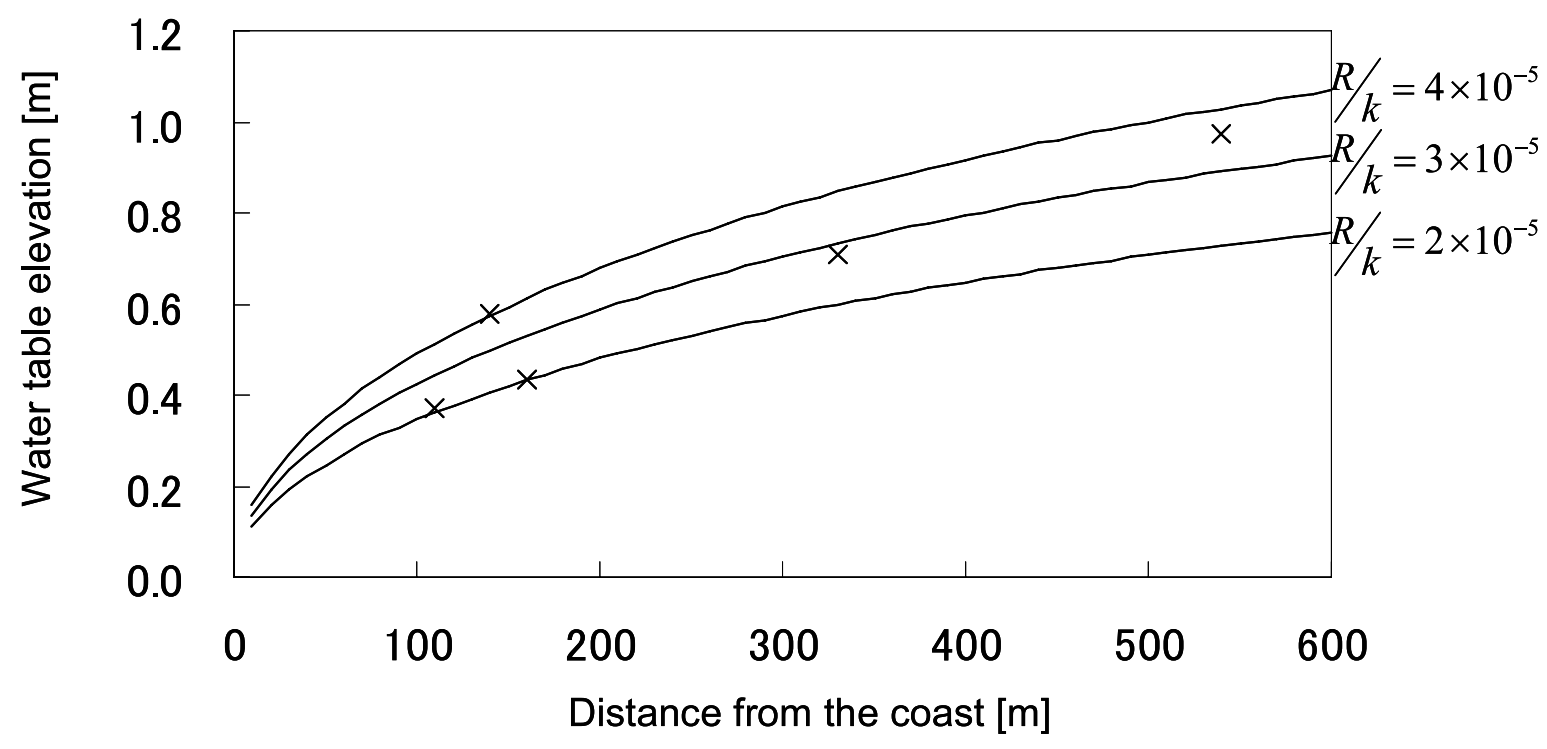

\section{$x$ : observed data}

図 9 Dupuit-Ghyben-Herzberg モデルによる地下水面標高推定結果と地下水面標高観測データの比較

Fig. 9 Comparisons between the calculated water table heights by the Dupuit-Ghyben-Herzberg model and the observed data

水量 $2275 \mathrm{~mm} /$ 年 (気象庁、2008) より、浸透量 の平年值はおよそ $680 \sim 1140 \mathrm{~mm} /$ 年 $(2.2 \sim 3.6$ $\times 10^{-8} \mathrm{~m} / \mathrm{s}$ ) となる。ここから、透水係数は、 $5 \times 10^{-4} \sim 2 \times 10^{-3} \mathrm{~m} / \mathrm{s}$ 程度と推定される。従っ て、本研究で推定した透水係数の範囲 $3.0 \times$ $10^{-4} \sim 3.4 \times 10^{-2} \mathrm{~m} / \mathrm{s}$ は、この結果と矛盾しない。

また、本研究で推定した透水係数と既存研究結 果を比較すると、揚水試験結果（新藤、1980）と は調和的であった（表 3)。一方で、現場透水試 験 (本間ほか、1974; 新藤、1980; 新島村建設課、 2001）および室内試験（本間ほか、1974；新藤、 1980 ; 新藤ほか、1989）によって得られた白ママ 層の透水係数と比べると、本研究で得られた值は、 既存研究の上限の值から 2 オーダー程度大きい值 であった（表 3）。室内試験結果に対して、この ような違いが生じる原因の一つとして、評価対象 とする領域や空間スケールが異なっていることが 挙げられる。本研究で用いた手法および DupuitGhyben-Herzberg モデル (Vacher, 1988) では、 海岸から各井戸まで、あるいは島全体の地盤を均 質と見なした場合の等価な透水係数を推定してい るのに対し、室内試験は試験片サイズの試料を対 象としているため、局所的な影響を受けやすいと
表 3 既存研究および本研究において求められた 白ママ層の透水係数

Table 3 Hydraulic conductivities of the Shiromama aquifer obtained from this study and from previous studies.

\begin{tabular}{|c|c|c|}
\hline 文献 & 透水係数 $(\mathrm{m} / \mathrm{s})$ & 試験方法 \\
\hline 本研究 & $3.0 \times 10^{-4} \sim 3.4 \times 10^{-2}$ & 2 潮汐応答の解析 \\
\hline \multirow[t]{2}{*}{ 本間ほか(1974) } & $1.85 \times 10^{-6} \sim 9 \times 10^{-5}$ & 現場透水試験 \\
\hline & $1.5 \times 10^{-5} \sim 1.9 \times 10^{-4}$ & 4 室内試験 \\
\hline \multirow[t]{3}{*}{ 新藤（1980） } & $2.0 \times 10^{-4} \sim 6 \times 10^{-3}$ & 揚水試験 \\
\hline & $1.25 \times 10^{-6 \sim 9 \times 10^{-5}}$ & 現場透水試験 \\
\hline & $1.2 \times 10^{-5} \sim 3.3 \times 10^{-4}$ & 4 室内試験 \\
\hline 新藤ほか（1989） & $4 \times 10^{-8} \sim 3 \times 10^{-4}$ & 室内試験 \\
\hline 新島村建設課 (2001) & $8.83 \times 10^{-6}$ & 現場透水試験 \\
\hline
\end{tabular}

考えられる。また、非定常法の単孔式現場透水試 験では、透水係数が $10^{-4} \mathrm{~m} / \mathrm{s}$ 以上の地盤では精 度が良くないことが知られており（西垣、1986）、 原位置の透水係数を適切に評価できていなかった 可能性がある。 


\section{6. 結論}

地下水面の潮汐応答から原位置の不圧帯水層の 物性を評価する際に必要な地下水面変動の理論解 を得るために、複数の分潮からなる海洋潮汐の境 界条件の下でBoussinesq 方程式を解析的に解い た。また、伊豆諸島の新島において地下水面変動 の時系列観測を行い、導いた解析解を用いたパラ メータフィッティングから、帯水層物性の評価を 試みた。その結果、透水量係数が $0.12 \sim 1.7 \mathrm{~m}^{2} / \mathrm{s}$ と推定された。振幅を用いて得られた透水量係数 と位相差を用いて得られたそれは互いによく一致 し、さらに、得られた透水量係数を用いて計算さ れた振幅及び位相差は観測結果と調和的であるこ とから、带水層パラメータは適切に評価できたも のと考えられる。また、井戸間での值の差は1オー ダー程度に収まっており、新島前浜海岸付近の白 ママ層は比較的均質な帯水層であると考えられ る。

\section{謝辞}

本研究は、科学研究費 (基盤研究 (A) No. 21254005）の一部として行われたものである。ま た、本研究の実施にあたり、新島本村地区内で地 下水位の連続計測が可能な井戸をご紹介頂いた山 本勉氏、現地で新島の地質に関してご教示頂いた 磯部一洋博士に感謝いたします。また、二名の匿 名査読者の有益なコメントにより本論文は改善さ れました。以上、記して感謝いたします。

\section{参考文献}

石黒真木夫 ·佐藤忠弘 - 田村良明 · 大江昌嗣 (1984）：

潮汐データ解析ープログラム BAYTAPの紹介一. 統 計数理研究所彙報、32、71 85 .

磯崎義正（1970）: 宮古島の地下水. 応用地質、11、 $12 \sim 25$.

磯部一洋 ·伊藤順一 (2003)：伊豆新島に単成火山群 を貫く島嶼部最長のトンネル出現. 地質ニュース、 592、35 43 .

浦越拓野 ·德永朋祥 · 茂木勝郎（2005）：海底地下水 湧出域に打ける間隙水圧連続測定による間隙水圧
場㧍よび水理特性評価の試み。地下水学会誌、47、 $181 \sim 197$.

気象庁 (2008) : 気象統計情報。気象庁ホームページ、 http://www.data.jma.go.jp/obd/stats/etrn/.

新藤静夫（1980）：火山島に打ける地下水の水収支に関 する研究一伊豆七島を例として一。文部科学省科学 研究費報告書、143p.

新藤静夫 · 秋山一弥 - 笠原 保 (1989) : 新島地下水調 査報告書、千葉大学理学部、22p.

第三管区海上保安本部海洋情報部（2008）：潮汐情

報、第三管区海上保安本部海洋情報部ホームページ、

http://wwwl.kaiho.mlit.go.jp/KAN3/.

新島村（1996）：『新島村史 通史編.』、新島村、 $1168 \mathrm{p}$. 新島村建設課 (2001)：新島村特定環境保全公共下水道

事業実施設計 地質調査報告書. 新島村、43p.

西垣 誠 (1986)：単孔式原位置透水試験法の諸問題.

地下水と井戸とポンプ、28（5)、1〜13.

細谷真一・徳永朋祥 (2008)：間隙水圧の気圧変動に対

する応答を利用した堆積岩の鉛直方向の透水係数の

評価. 土木学会論文集 C、64（2）、238～252.

本間 仁 · 荻原国宏 · 新藤静夫 (1974) : 新島の地下水

についての調查と解析. 土木学会論文報告集、222、 $79 \sim 92$.

Bear, J. (1972): Dynamics of fluids in porous media. Elsevier, New York, 764p.

Carol, E. S., E. E. Kruse, J. L. Pousa, and A. R. Rolg (2009): Determination of heterogineities in the hydraulic properties of phreatic aquifer from tidal level fluctuations: a case in Argentina. Hydrogeology J., 17, $1727 \sim 1732$.

Jha, M. K., Y. Kamii and K. Chikamori (2003): On the estimation of phreatic aquifer paramters by the tidal response technique. Water Resources Management, 17, $69 \sim 88$.

Jha, M. K., D. Namgial and Y. Kamii (2008): Hydraulic parameters of coastal aquifer systems by direct methods and an extended tide-aquifer interaction technique. Water Resour. Manage., 22, 1899 1923.

Parlange, J. Y., F. Stagnitti, J. L. Starr and R. D. Braddock (1984): Free-surface flow in porous media and periodic solution of the shallow-flow approximation. $J$. Hydrology, 70, $251 \sim 263$.

Rojstaczer, S. (1988): Determination of fluid flow 
properties from the response of water levels in wells to atmospheric loading. Water Resour. Res., 24, 1927 1938.

Rojstaczer S. and D. C. Agnew (1989): The influence of formation material properties on the response of water levels in wells to Earth tides and atmospheric loading. J. Geophys. Res., 94 (12), $403 \sim 411$.

Rotzoll, K., A. I. El-Kadi and S. B. Gingerich (2008): Analysis of unconfined aquifer subject to asynchronous dual-tide propagation. Ground Water, 46 (2), 239 250.

Shih, D. C. and G. Lin (2004): Application of spectral analysis to determine hydraulic diffusivity of a sandy aquifer (Pingtung County, Taiwan). Hydrol. Process., 18, $1655 \sim 1669$.

Song, Z., Li, L., Kong, J. and H. Zhang (2007): A new analytical solution of tidal water table fluctuations in a coastal unconfined aquifer, J. Hydrology, 340, 256 260 .

Tamura, Y., T. Sato, M. Ooe and M. Ishiguro (1991): A procedure for tidal analysis with a Bayesian information criterion. Geophysical Journal International, 104, $507 \sim 516$.

Vacher, H. L. (1988): Dupuit-Ghyben-Herzberg analysis of strip-island lenses. GSA Bulletin, 100 (4), 580 591.

Wang, K., and E. E. Davis (1996): Theory for the propagation of tidally induced pore pressure variations in layered subseafloor formations. J. Geophys. Res., 101 (B5), $11483 \sim 11495$.

(受付 : 2010 年 7 月 21 日、受理 : 2011 年 5 月 9 日) 